\title{
Fluvial organic carbon flux from an eroding peatland catchment, southern Pennines, UK
}

\author{
R. R. Pawson, D. R. Lord, M. G. Evans, and T. E. H. Allott \\ Upland Environment Research Unit, Geography, School of Environment and Development, Arthur Lewis Building, \\ University of Manchester, Oxford Road, Manchester, M13 9PL, UK
}

Received: 15 January 2007 - Published in Hydrol. Earth Syst. Sci. Discuss.: 4 April 2007

Revised: 19 November 2007 - Accepted: 20 February 2008 - Published: 20 March 2008

\begin{abstract}
This study investigates for the first time the relative importance of dissolved organic carbon (DOC) and particulate organic carbon (POC) in the fluvial carbon flux from an actively eroding peatland catchment in the southern Pennines, UK. Event scale variability in DOC and POC was examined and the annual flux of fluvial organic carbon was estimated for the catchment. At the event scale, both DOC and POC were found to increase with discharge, with event based POC export accounting for $95 \%$ of flux in only $8 \%$ of the time. On an annual cycle, exports of $35.14 \mathrm{t}$ organic carbon (OC) are estimated from the catchment, which represents an areal value of $92.47 \mathrm{~g} \mathrm{C} \mathrm{m}^{-2} \mathrm{a}^{-1}$. POC was the most significant form of organic carbon export, accounting for $80 \%$ of the estimated flux. This suggests that more research is required on both the fate of POC and the rates of POC export in eroding peatland catchments.
\end{abstract}

\section{Introduction}

There is a wide range of literature investigating the fluvial export of organic carbon from peatland environments (e.g. Hope et al., 1997a; Dawson et al., 2002; Worrall et al., 2003). Much of this research has been focussed on estimating total fluvial losses of organic carbon in the form of DOC (dissolved organic carbon) and POC (particulate organic carbon), especially in light of current and potential climatic changes and the likely impacts of such changes on the soil carbon store. Understanding POC and DOC losses and their impact on upland carbon budgets is essential in light of potential future climate changes and targets for carbon sequestration set

Correspondence to: R. R. Pawson

(richard.pawson@manchester.ac.uk) by the Kyoto Protocol. In the UK the largest component of soil carbon storage is present in upland peat soils (Worrall et al., 2003; Wallage et al., 2006). Integrated studies of riverine export have shown an important link between terrestrial and oceanic carbon storage (Kempe, 1979; Hope et al., 1997b). In most studies that have evaluated the total losses of DOC and POC through upland fluvial systems, DOC is identified as the most significant form of carbon export. For example, Hope et al. (1997a) assessed two contrasting rivers in NE Scotland. Of these, DOC export accounted for greater than $75 \%$ of the total fluvial loss. Similarly, Tipping et al. (1997) investigated a range of catchments of the River Humber, and found DOC to account for between 51 and $80 \%$ of export. In contrasting catchments in Mid-Wales and NE Scotland, Dawson et al. (2002) found DOC contributed 69 and 88\% of fluvial export, respectively. In a much broader assessment of fluxes, Hope et al. (1997b) concluded that for British rivers as a whole during $1993,0.68 \mathrm{Mt} \mathrm{C}$ of the fluvial carbon load was in dissolved form, representing $77 \%$ of fluvial loss. However, one of the main limitations of these data is the use of fixed-interval sampling regimes, whereas in reality the flux of POC is highly episodic, related to high flow hydrological events (Hope et al., 1997a). Hence the analysis of fine temporal resolution of POC fluxes is important for improving our understanding of POC flux and load estimates.

A clear understanding of the dynamics of DOC and particularly POC flux in eroding systems is essential for efforts to model current upland carbon cycles, to predict changes in peatland carbon sinks in the future, and to manage soil carbon in peatland environments. One significant gap in current knowledge is that almost all of the previous work on POC/DOC proportions has been carried out in relatively intact peatlands. This is despite the fact that significant areas

Published by Copernicus Publications on behalf of the European Geosciences Union. 


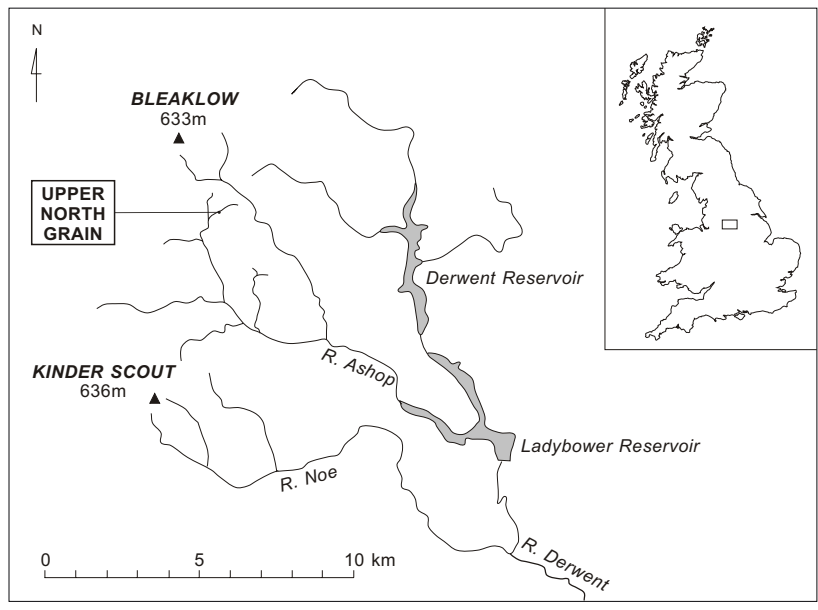

Fig. 1. Location of study site Upper North Grain (UNG) in the Southern Pennines.

of UK peatland systems are significantly eroded (Tallis et al., 1997) and that these may provide contemporary examples of the future states of wider spread areas of peatlands given predicted environmental change (Evans et al., 2006). As yet, sediment flux has not been studied explicitly for the comparison of POC and DOC flux in heavily eroded peatland systems. The most impacted catchment for which data exists is at Moor House in the north Pennines (Worrall et al., 2003), a system which is extensively eroded but shows evidence of widespread re-vegetation (Evans and Warburton, 2005). Worrall et al. (2003) calculated an overall carbon budget for this system and found POC to be the largest flux, accounting for $\sim 68 \%$ of fluvial carbon flux. Re-vegetation of eroded north Pennine peatlands has led to much reduced erosion rates compared to the severely degraded peatlands of the southern Pennines (Evans et al., 2006), described as the most eroded in Britain (Rothwell et al., 2005). These "badland" landscapes (Tallis, 1997) represent the extreme end of a spectrum which runs to the relatively uneroded, DOC dominated systems studied by Hope et al. (1997a). The onset of peatland gully erosion in the southern Pennines correlates closely with climatic fluctuations in the Early Medieval Warm Period (Tallis, 1995, 1997). Predicted future climate changes, including warmer and drier summers, have the potential to exacerbate existing peat erosion and initiate further instability in these environments. Therefore, research into sediment and in particular POC fluxes are essential in these fragile upland systems.

This study aims to quantify and compare the relative roles of DOC and POC in the fluvial export of carbon from an actively eroding, peat dominated catchment in the southern Pennines, based on intensive monitoring data and modelling annual cycles. Sediment removal in peatlands has been investigated in the past (e.g. Labadz et al., 1991), and the importance of stormflow in sediment yields highlighted in up-

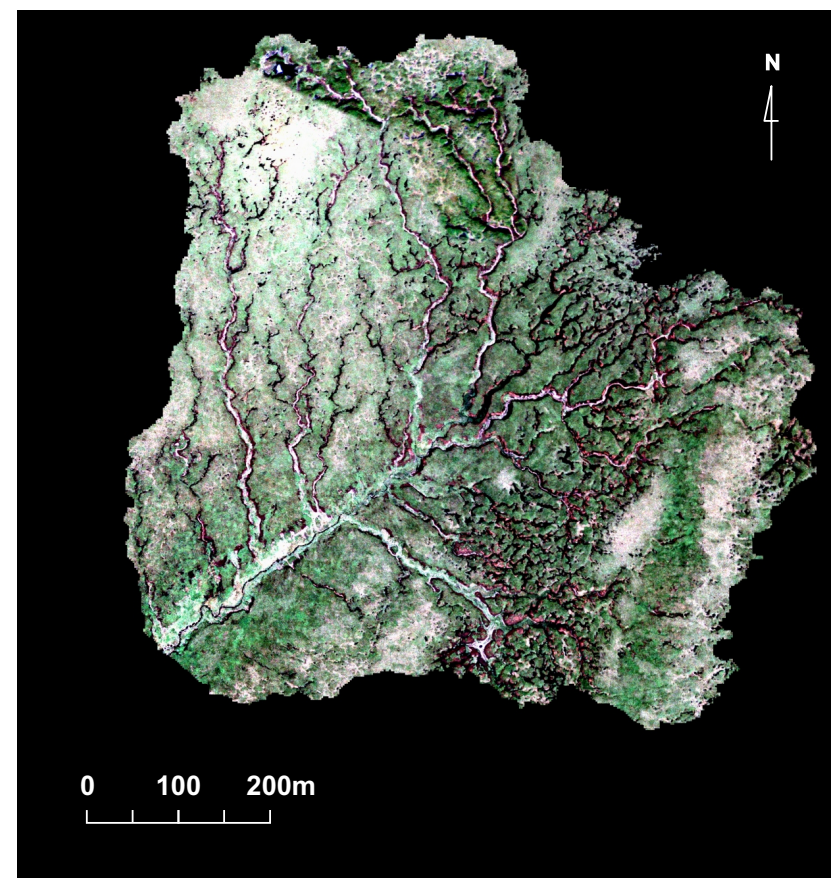

Fig. 2. Arial photograph of UNG catchment displaying the blue, green and near infrared bands. The dendritic gulley networks are clearly visible.

land peatland catchments (Evans et al., 2005). Due to the low density of peat sediments (Labadz et al., 1991), it is likely that carbon contents will vary with discharge as a function of stream power, and this has been shown in some cases in the literature (e.g. Tipping et al., 1997). This is due to the channel entraining varied portions of minerogenic sediments under different discharge conditions. Such variability of sediment in terms of quantity and quality should be considered when modelling annual carbon fluxes. However, it is widely accepted that the dominant control on suspended sediment in peat systems is the supply and linkage of the erodable sediments to the channel - the concept of slope channel linkage (Evans and Warburton, 2005). With this in mind, the first part of this paper investigates the nature of carbon export through an intensive field campaign during and between storm events. Using empirical observations from this high temporal resolution data, annual flux estimates of both POC and DOC are modelled to outline the significance of each form of carbon export in heavily eroding peatland systems.

\section{Methodology}

\subsection{Study site}

The field site used in this study is Upper North Grain (UNG), a small headwater catchment of the River Ashop (see Figs. 1 and 2). This is part of the National Trust High Peak Estate, 
situated in the Peak District, southern Pennines, UK. Located at altitudes between 490 and $541 \mathrm{~m}$ OD and receiving approximately $1200 \mathrm{~mm}$ rainfall each year, the catchment is dominated by blanket bog. The catchment is relatively small, draining an area of $0.38 \mathrm{~km}^{2}$, with rough grazing by sheep as the dominant land-use (Rothwell et al., 2005). The catchment is heavily eroded with Bower Type I peat gullies (Bower, 1961), which in the upper reaches occur solely in a peat stratigraphy which often reach several metres in depth. The lower reaches of the gullies cut into the underlying bedrock, which is dominated by sandstones of the Millstone Grit Series (Wolverson-Cope, 1976). The sampling site for this study is located in these lower reaches of the catchment where the river channel flows on bedrock surfaces rather than within the deep peat stratigraphy.

\subsection{Field sampling: short-term temporal variability}

To assess short-term temporal variability of organic carbon fluxes, a period of intense field monitoring was undertaken. Over a two week period, stream water samples were taken from Upper North Grain on an hourly basis using a Sigma 900 automatic water sampler. This monitoring took place in late March/early April 2005 during a period of storm events. Following each $24 \mathrm{~h}$ period, stream water samples were returned to the laboratory and processed using the methods outlined below. Laboratory work was undertaken within $72 \mathrm{~h}$ of sampling. The data set therefore consisted of over $300 \mathrm{di}-$ rect measurements of DOC, $\mathrm{pH}$, conductivity and suspended sediment. During this period, stage was recorded using an Intelysis pressure transducer and Sentry II data logger. A stage-discharge relationship (see Daniels, 2006) was used to determine discharge over the study period.

\subsection{Field sampling: annual flux calculation}

Water samples were taken using a range of methods throughout 2005-2006. Sampling periods were distributed throughout the period and occurred at a wide variety of discharges. Samples included routine spot samples on a weekly to biweekly basis, low flow sampling and storm discharge samples, each of which is summarised in Table 1. All samples were returned to the laboratory, stored in a dark cold room at $4^{\circ} \mathrm{C}$, processed and analysed within $72 \mathrm{~h}$ of sampling from the catchment.

Along with water samples, monitoring of stream discharge was undertaken at 15-min intervals, providing a quasi-continuous field dataset. Monitoring encompassed the entire period, facilitated again by Intelysis probes and data loggers.

A range of sediment samples from the catchment were characterised in terms of carbon content. This was undertaken to allow identification of in-catchment sources of fluvial carbon, which could then be used to estimate organic carbon flux from the peatland carbon store. This source char- acterisation entailed analysis of a range of potential source sediments taken from a wide area in the catchment. Potential source sediments were generalised as sandstones and mudstones of the Millstone Grit Series, the periglacial head deposits of reworked sandstones and mudstones and the peat itself. Five exposures of the main sediment types were selected with broad spatial coverage in the catchment, while peat samples were taken from eroding gulley walls and through peat coring. The method for peat core collection is summarised by Rothwell et al. (2005). All catchment sediment samples were analysed using the methods described below.

\subsection{Laboratory methods}

Stream water samples were vacuum filtered through preweighed Whatman GF/C glass microfibre filter paper circles to separate the suspended sediment fraction over $1.2 \mu \mathrm{m}$. Water volume of the filtrate was also measured. The sediment retained on the filter paper was dried for $24 \mathrm{~h}$ at $105^{\circ} \mathrm{C}$ to eliminate hygroscopic water and ensure accurate sediment weight. The filter papers were then re-weighed to determine suspended sediment concentration (SSC) as a function of water volume. The separated water and sediments were then analysed as described below.

\subsubsection{Sediment analysis}

Due to the operational limits of instrumentation, sediment samples of over $50 \mathrm{mg}$ were milled using a silicon carbide grinder in a $240 \mathrm{~V}$ Glen Crest Ball mill. This homogenised the sediment and filter paper which allowed repeated analysis of larger samples to determine the reproducibility of analytical techniques. Filter papers with less than $50 \mathrm{mg}$ of sediment were left intact as the expected carbon content of this amount of sediment is within the range of measurement of laboratory instruments (R. Pawson, unpublished data). All samples were analysed for organic content using Loss on Ignition (LOI) techniques (e.g. Armstrong, 2005). A calibration was then derived for carbon contents of organics by analysing total carbon and total inorganic carbon using an SSM 5000A of the Shimadzu TOC-V Series Analyser. POC content was determined by total carbon minus total inorganic carbon. The use of such a calibration is typical of POC load investigation (e.g. Worrall et al., 2003; Evans et al., 2006). This allowed the calculation of POC concentration from organics analysis. This calibration would be specific to this research although comparable with other examples.

\subsubsection{Water analysis}

After stream water samples had been filtered through the $1.2 \mu \mathrm{m}$ filter paper, each water sample was then filtered again using $0.45 \mu \mathrm{m}$ Whatman cellulose nitrate membrane. Subsamples of the filtrate were analysed for TOC (Total Organic Carbon) using the Shimadzu TOC-V Series Analyser. The 
Table 1. A record of the samples used for the POC-discharge calibration for annual load estimates in this study.

\begin{tabular}{llll}
\hline Sample type & Dates & Number of samples & Description \\
\hline $\begin{array}{l}\text { Routine spot samples of main UNG mon- } \\
\text { itoring point }\end{array}$ & November 2005-December 2006 & 35 samples & $\begin{array}{l}\text { Weekly to bi-weekly rou- } \\
\text { tine sampling }\end{array}$ \\
$\begin{array}{l}\text { High discharge sampling of main UNG } \\
\text { monitoring point }\end{array}$ & November 2005-December 2006 & 20 samples & $\begin{array}{l}\text { Grab samples collected at } \\
\text { points of storm discharge } \\
\text { Storm Sampling (AWS) }\end{array}$ \\
& February 2004-February 2006 & $\begin{array}{l}24 \text { samples for 6 High discharge, flow trig- } \\
\text { events, 48 for 1 event gered sampling using AWS }\end{array}$ \\
\hline
\end{tabular}

$0.45 \mu \mathrm{m}$ filtration size was used as this pore size is the common definition for DOC including colloidal carbon (Koelmans and Prevo, 2003) and has been routinely used in numerous studies for DOC determination (e.g. Scott et al., 1998; Fujii et al., 1998; Chow et al., 2005).

\section{Results: temporal variability of organic carbon flux}

Figure 3 shows the results from the two week intensive study period. The discharge record shows relatively consistent, low values during the first nine days except for two main events where discharge rapidly increases over $0.01 \mathrm{~m}^{3} \mathrm{~s}^{-1}$ and then returns to low flow. This nine day spell is then followed by more variable discharges with greater ranges of flow. As in the first nine days of monitoring, flows in the later part of monitoring are flashy and after a rapid peak in discharge, baseflow conditions are soon resumed.

DOC concentrations in the sample period vary by $\sim 20 \mathrm{mgl}^{-1}$. Higher peaks in concentration of up to $\sim 25 \mathrm{mg} \mathrm{l}^{-1}$ coincide with discharge peaks, although the degree of increasing DOC does not relate to the level of discharge increase. Closer analysis of the relationship of DOC with discharge reveals the presence of short term hysteresis, where DOC is offset both prior to and following discharge peaks. Following these peaks, DOC concentrations gradually decline to $\sim 5 \mathrm{mg} \mathrm{l}^{-1}$. This trend of rapid peaks and slow decreases of concentration is most pronounced in the first nine day period of relatively lower discharges. In the later period of more variable and increased discharge, DOC concentrations remain relatively higher, with lowest concentrations of $\sim 10 \mathrm{mg} \mathrm{l}^{-1}$.

POC concentrations over the monitoring period are much more variable, with the greater values concentrated in the period after nine days. The preceding period shows very little change in POC concentration, with low values of $1-2 \mathrm{mg}^{-1}$. In the later period, concentration peaks of up to $\sim 250 \mathrm{mg}^{-1}$ are recorded. These POC peaks are more short-lived than those of discharge. For example, the samples one hour before and one hour after the maximum peak of $250 \mathrm{mg} \mathrm{l}^{-1}$ have values of 4 and $50 \mathrm{mgl}^{-1}$ respectively, while concentrations of $4 \mathrm{mg} \mathrm{l}^{-1}$ are returned within $5 \mathrm{~h}$ of this peak.
DOC flux over the monitoring period was $128 \mathrm{~kg}$; POC flux was $145 \mathrm{~kg}$. Both fluxes were calculated using Eq. (1):

Total Load $=K \sum_{i=1}^{n}(\mathrm{Ci} Q m)$

where; $K$ is a conversion factor to take into account the period of study, $C i$ is the concentration for each sample point, $Q m$ is the volumetric discharge for the time unit of each sample concentration and $n$ is the number of samples. This equation is similar to that used by Walling and Webb (1981) except that volumetric discharge is used rather than mean discharge.

These figures give a total carbon flux for the two week monitoring period of $276 \mathrm{~kg}$. Of this value, POC represents $\sim 54 \%$ of carbon flux. Cumulative flux data show that for DOC, $95 \%$ of total flux (or $121 \mathrm{~kg}$ ) was exported over $\sim 62 \%$ of time. For POC the $95 \%$ flux value of $141 \mathrm{~kg}$ was exported in $\sim 8 \%$ of time during the study period - or in just over 1 day.

\subsection{Modelling annual carbon flux: DOC}

\subsubsection{Model inputs}

Annual DOC flux was calculated from the routine samples collected from 2005-2006 during an annual field campaign. The annual load of DOC export was then estimated using an interpolation method ("Method 5") from Walling and Webb, (1985):

Toal Load $=K \frac{\sum_{i=1}^{n}(C i Q i)}{\sum_{i=1}^{n} Q i} Q r$

where $K$ is a conversion factor to take into account the period of study, $C i$ is the concentration for each sample point, $Q i$ is the discharge at each sample point, $Q r$ is the average discharge over the study period and $n$ is the number of samples. This is the preferred method for flux estimates given the available data (Littlewood, 1992) and is common in the literature for estimates of OC loads (e.g. Hope et al., 1997; Dawson et al., 2002; Worrall et al., 2003a, b; Worrall and Burt, 2005). This aids the comparisons between these results and pre-existing data.

For annual flux, it is necessary to correct the final figure of DOC export for the input of $\mathrm{C}$ to the catchment via rainfall. 

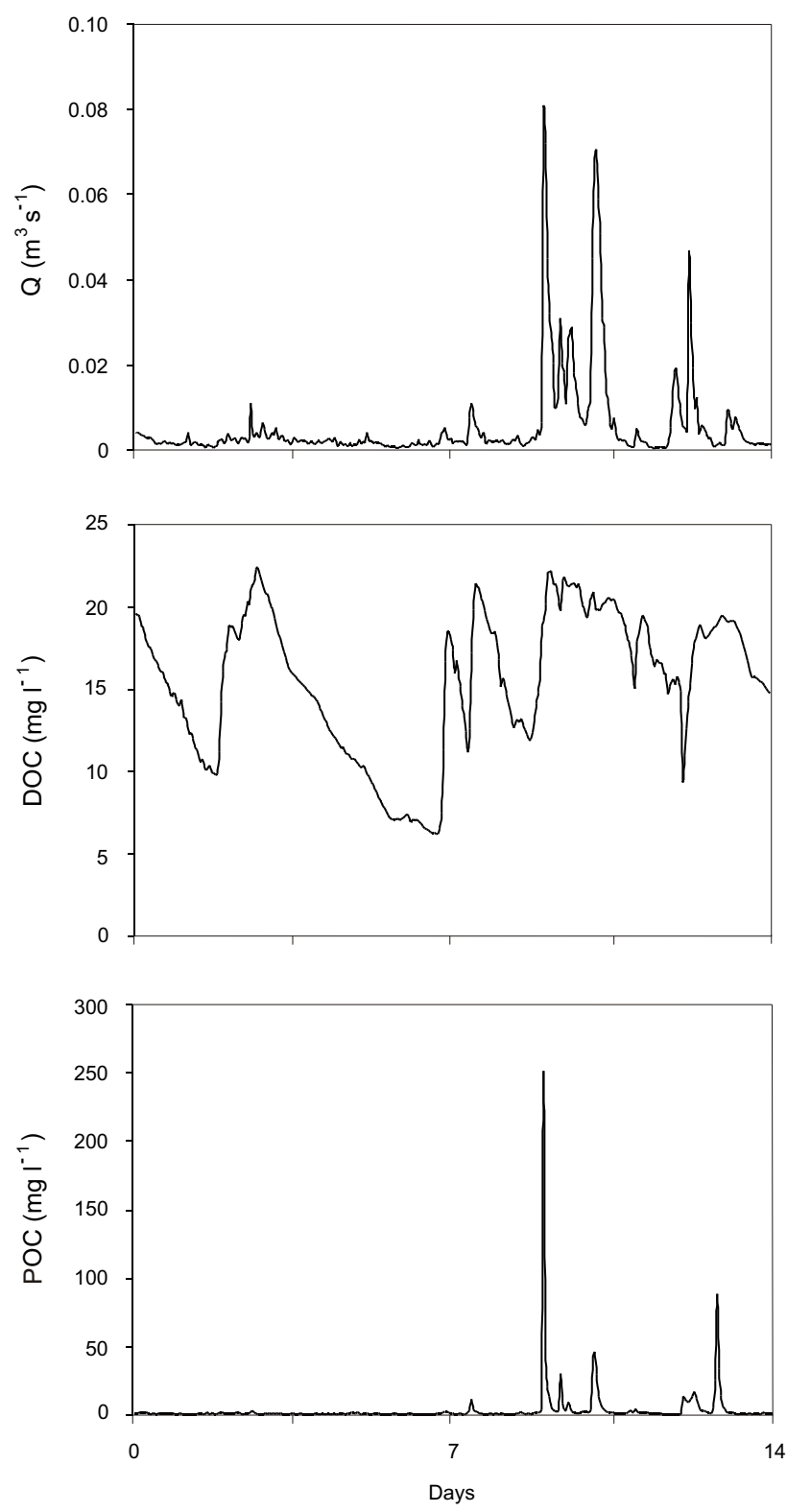

Fig. 3. Discharge, DOC and POC concentration data for the two week intensive study period. Note the changing $y$-scale.

Analysis of rainfall has not been undertaken for this study, so values reported by Worrall et al. (2003) are used to estimate the peat sourced DOC flux.

\subsubsection{Model outputs}

Interpolated DOC gives an annual DOC flux of $18.49 \mathrm{~g} \mathrm{C}$ $\mathrm{m}^{-2} \mathrm{a}^{-1}$. This estimate of DOC flux is a total flux (i.e. peat sourced and atmospherically sourced DOC). Using data presented by Worrall et al. (2003), peat sourced DOC flux at UNG is $15.39 \mathrm{~g} \mathrm{C} \mathrm{m}^{-2} \mathrm{a}^{-1}$ or an absolute flux of $5.85 \mathrm{t} \mathrm{C}$ using Eq. (2).

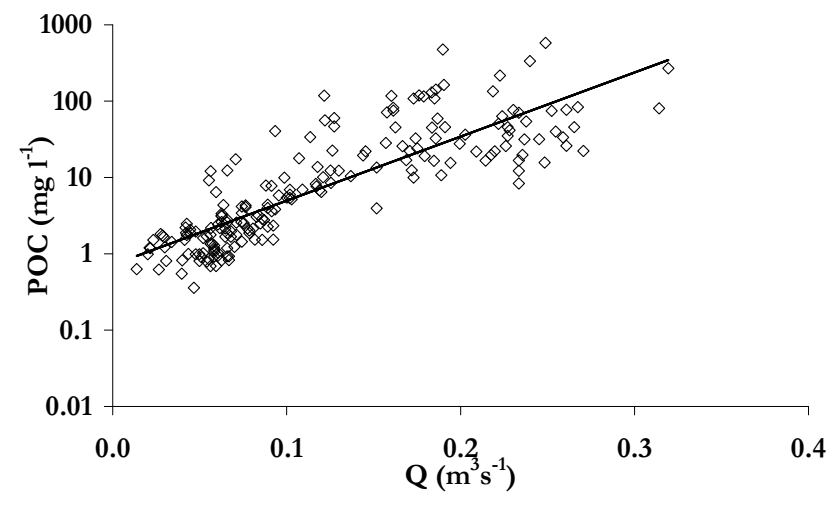

Fig. 4. POC-discharge rating curve $\left(r^{2}=0.72 ; p=<0.01\right)$ for estimating annual POC loads from Upper North Grain.

\subsection{Modelling annual carbon flux: POC}

\subsubsection{Model inputs}

POC flux was modelled for the annual period using a sediment rating curve approach and the analysis of POC concentrations in the suite of sediment samples collected from the catchment. A rating curve was derived from 247 water samples from UNG, collected between November 2005 and December 2006 (see Table 1). Previous work in peatland streams has demonstrated that there is usually positive hysteresis in the suspended sediment-discharge rating relation (e.g. Evans et al., 2006; Rothwell, 2006). Therefore, a 45 min lag was used in the construction of the rating curves, i.e. POC was related to $Q_{t+30}$. Back transformation errors for the sediment yield was corrected using the smearing estimator, since this technique is the most appropriate correction for sediment rating curves in peatland streams where data has been transformed such as in this case (Armstrong et al., 2006).

For the two week intensive study, OC concentrations were obtained for every hourly sample. This data could then be calibrated to POC using the OC/POC relationship obtained for the annual flux. These concentrations were then converted to total export of POC using Eq. (1), yielding POC export for the two week intensive monitoring period.

\subsubsection{Model outputs}

The mean POC proportion for organic sediment loads was calculated as $48.12 \pm 4.10 \%$ ( $n=47,95 \%$ confidence). This is similar to POC proportions reported by Worrall et al. (2003) after Francis (1987), where the majority of upland suspended sediment is organic-rich, and that carbon makes up $\sim 50 \%$ of this load. This $\sim 50 \%$ load is confirmed by measurement of OC contents of a range of peat samples at UNG, in which carbon contents where $50.1 \pm 1.70 \%$ (95\% confidence). Characterisation of other sediment sources measured very low total carbon (TC) concentrations similar to the conclusions 
Table 2. Ranges of reported OC fluxes in the literature, along with notes on the catchments studied and the source of data. * denotes that the loads have been inferred from reported organic sediment concentrations and applying 50\% C rule (e.g. Francis, 1987; Worrall et al., 2003).

\begin{tabular}{|c|c|c|c|}
\hline Catchment location \& observed characteristics & DOC flux $\mathrm{g} \mathrm{C} \mathrm{m}^{-2} \mathrm{a}^{-1}$ & POC flux $\mathrm{g} \mathrm{C} \mathrm{m}^{-2} \mathrm{a}^{-1}$ & Source \\
\hline $\begin{array}{l}\text { North Pennines, UK - } \\
\text { blanket peat and organic soils }\end{array}$ & $7.0-15.0$ & NA & Scott et al. (1998) \\
\hline $\begin{array}{l}\text { North east Scotland - } \\
\text { blanket bog with heather moorland }\end{array}$ & 16.9 & 1.85 & Dawson et al. (2002) \\
\hline $\begin{array}{l}\text { Upper Hafren, Mid-Wales - } \\
\text { acid, grass dominated moorland }\end{array}$ & 8.35 & 2.74 & Dawson et al. (2002) \\
\hline $\begin{array}{l}\text { North Pennines, UK - } \\
\text { blanket bog }\end{array}$ & $9.4-15.0$ & 19.9 & Worrall et al. (2003) \\
\hline $\begin{array}{l}\text { Humber River, UK - } \\
\text { range of catchment types }\end{array}$ & $2.3-5.4$ & $0.7-3.2$ & Tipping et al. (1997) \\
\hline $\begin{array}{l}\text { Britain - } \\
\text { nationwide survey of } 85 \text { regions }\end{array}$ & $0.77-10.35$ & 5.7 & Hope et al. (1997b) \\
\hline $\begin{array}{l}\text { North east Scotland - } \\
\text { range of catchments }\end{array}$ & $1.34-11.5$ & $0.1-8.53$ & Hope et al. (1997a) \\
\hline $\begin{array}{l}\text { Derbyshire, UK } \\
\text { peatland reservoir sediment cores }\end{array}$ & NA & $15.65^{*}$ & Hutchinson (1995) \\
\hline $\begin{array}{l}\text { Yorkshire, UK } \\
\text { gullied blanket peatland }\end{array}$ & NA & $19.41^{*}$ & Labadz et al. (1991) \\
\hline $\begin{array}{l}\text { Central Wales - } \\
\text { eroding blanket bog }\end{array}$ & NA & $17.2^{*}$ & Francis (1990) \\
\hline
\end{tabular}

made by Spears and Amin (1981). Total carbon contents of $2.30 \pm 1.50 \%$ for shale, $0.17 \pm 0.07 \%$ for sandstone and $1.09 \pm 0.73 \%$ for head deposits were recorded in this study. Of the source sediments, organic carbon measurement was below the range of measurement of the analytical methods employed, suggesting that there was no need to correct carbon contents of fluvial suspended sediment samples for nonpeat organic carbon, as any potential sources are negligible.

The POC-discharge rating curve (Fig. 4) was applied to the annual discharge record at UNG for 2006. This model produced a total POC flux of $28.11 \mathrm{t} \mathrm{C}$, equivalent to $73.97 \mathrm{~g}$ $\mathrm{C} \mathrm{m}^{-2} \mathrm{a}^{-1}$. As described above, this requires no correction for significant non-peat $\mathrm{OC}$ sources.

Based on the modelled DOC and POC flux data the total annual flux for peat sourced carbon (the fluvial loads minus the inputs of rainfall DOC) from UNG is $92.47 \mathrm{~g} \mathrm{C} \mathrm{m}^{-2} \mathrm{a}^{-1}$. This amounts to an absolute flux of $35.14 \mathrm{t} \mathrm{C}$, of which POC accounts for $80.0 \%$.

\section{Discussion}

\subsection{Fluxes of organic carbon}

The flux of both DOC and POC can be considered on both the short and annual scale. Estimation of carbon flux over the two week intensive monitoring period resulted in a total loss of $\sim 276 \mathrm{~kg}$. Of this, POC accounted for $\sim 148 \mathrm{~kg}$, equivalent to $\sim 54 \%$. This highlights the relative importance of POC in fluvial export, especially when considering the very low POC loads in the first nine days of the monitoring campaign.

The annual data provides a more striking insight of the relative roles of fluvial carbon export in eroding peatland catchments. The peat sourced carbon flux is $35.14 \mathrm{t} \mathrm{C} \mathrm{a}^{-1}$. This value has been derived using the interpolated DOC load and the POC-discharge calibration. Therefore, for the total carbon export value, POC accounts for $80.0 \%$ of fluvial export in the catchment. This clearly highlights the significance of POC in upland eroding peatland systems such as UNG, especially when this value is compared to those previously reported in the literature. Normalising the flux to unit area allows comparison with previous work (Table 2). With these in mind, the estimate of POC flux from UNG of $73.97 \mathrm{~g} \mathrm{C}$ $\mathrm{m}^{-2} \mathrm{a}^{-1}$ is significantly greater than many other examples. The implication is that in severely eroding catchments rates of POC export may be much higher than has previously been recognised.

Total DOC flux from the UNG catchment is higher than many values previously cited in the literature. The total flux of DOC from the catchment was estimated as $18.49 \mathrm{~g}$ $\mathrm{C} \mathrm{m}^{-2} \mathrm{a}^{-1}$, which was corrected to remove rainfall DOC as $15.39 \mathrm{~g} \mathrm{C} \mathrm{m}^{-2} \mathrm{a}^{-1}$. Reported values from other headwater peatlands are generally lower than these values As such, the flux of DOC from UNG is at the upper end of literature examples, particularly if we consider that most of these figures do not remove a volume of rainfall DOC as in this example. A possible explanation for this high value is the eroded 
nature of the catchment. Extensive gully networks are likely to cause a depressed water table over a wider area of the catchment by increasing drainage (Tallis, 1973; Wallage et al., 2006). This expands the aerobic zone and thus raises DOC production (Worrall and Burt, 2005) and consequently leads to a higher annual flux of DOC per unit area. This suggests that the importance of enhanced carbon flux from eroding catchments in upland carbon cycles may extend beyond particulate export as DOC fluxes may also be significantly higher under such conditions. The exception to this hypothesis is data presented for a catchment in NE Scotland where DOC load estimates reaches maxima of $21.5 \mathrm{~g} \mathrm{C} \mathrm{m}^{-2} \mathrm{a}^{-1}$ (Dawson et al., 2004). There is no suggestion in this example that the catchment is excessively degraded by natural erosion or land uses that might alter hydrology (such as gripping). As such, the hypothesis requires further testing in catchments with a wider range of gully erosion or gripping practices.

Although the significance of POC in the carbon flux from eroding peat catchments is clear, the question of how this source interacts with atmospheric carbon cycles is less well understood. Evans et al. (2006) estimate oxidation from peat surfaces as residual wastage and predict that $30-40 \%$ of bare peat loss can be attributed to oxidation. Similarly Jacinteh et al. (2002) show that $29-46 \%$ of soil organic carbon eroded from fields in Ohio is mineralised within 100 days. Current research has shown that in controlled experimental conditions up to $25 \%$ of mass can be lost from peat samples on an annual cycle and that this figure can reach $40 \%$ on a monthly scale (Pawson et al., 2006). If these figures are accurate and we consider the levels of POC flux presented in this paper, it appears that there is indeed a significant degree of atmospherically active carbon flux from eroding catchments. Work assessing such fates of POC is ongoing.

4.2 Temporal variability of carbon flux: implications for sampling

The results from the intensive two week period clearly demonstrate the episodic nature of POC export. For the majority of the period, POC concentrations are considerably lower than during the main period of export (Fig. 3). Such rapid, episodic, discharge related flux of POC is expected. Previous work investigating sediment dynamics in peatland systems (e.g. Labadz et al., 1991; Holden and Burt, 2002) has revealed positive hysteresis in discharge-sediment relations, attributed to sediment supply from peat surfaces (Evans et al., 2005). It therefore follows that POC concentrations, strongly affected by erosional inputs in these degrading systems, will exhibit similar characteristics. POC as a proportion of total sediment flux also varied with discharge (Fig. 4). This variability shows a trend of decreasing \% POC as discharges and SSC increases. Similar sediment quality-discharge relationships have been attributed to increased mineral entrainment (Bradley and Lewin, 1982; Dawson and Macklin, 1998; Rothwell et al., 2007). At lower discharges low density peat sediments make up a higher proportion of sediment loads and thus higher percentage POC is recorded. Even though $\%$ POC is higher in these lower discharge periods, actual POC concentrations are still significantly lower than during higher discharge events, (e.g. $\sim 250 \mathrm{mg}^{-l}$ peak, compared to $1-2 \mathrm{mg} \mathrm{l}^{-l}$ at low flow). The idea of variable organic component is supported by loss on ignition measurements of suspended sediment at a range of discharges (R. Pawson, unpublished data). These results suggest that POC flux analysis requires carefully constructed sampling regimes at a variety of discharge conditions. As sediment supply is usually the controlling factor for sediment flux (Evans et al., 2005), then it is also essential that POC flux work investigates a wide spectra of antecedent, prevailing conditions. For example, high discharge conditions may not necessarily result in greater POC flux if antecedent conditions are not suitable for sediment preparation. The need for careful field sampling is reinforced in the present study. Firstly, POC concentrations decrease rapidly following peaks, returning to a "prepeak" value within a few hours. The majority of POC flux $(95 \%)$ therefore occurs in a small amount of time. As such, infrequent periodic sampling will miss peaks of POC export. Conversely, if sampling only occurs during a peak then POC export could be significantly over estimated as peak concentrations are extrapolated beyond their true timescale. Furthermore, the POC-discharge relationship shows considerable hysteresis. The largest peak of POC over the period (Fig. 3) follows the first significant discharge peak ( $Q=0.09)$ after nine days of low flow. Following this, discharge is much more variable. A similar peak $(Q=0.07)$ occurs $27 \mathrm{~h}$ after the first peak. However, this second event results in a much lower peak POC concentration. The reduction most likely represents a sediment exhaustion effect due to the limited pre-storm period for sediment preparation by weathering. In general the storm POC concentrations are significantly higher than those reported elsewhere (e.g. Dawson et al., 2002). Observation of sediment supply related hysteresis in the POC-discharge relation suggests that suitable antecedent conditions are likely to be required to create high peaks in POC export, and that monitoring regimes need to consider these ideas carefully.

DOC concentrations also showed variability over the study period, but with a much lower range of values. Whereas POC ranged from $0-250 \mathrm{mg}^{-l}$, DOC has a range of 6.20 $22.4 \mathrm{mgl}^{-l}$. These concentrations appear lower than reported values mentioned above, but it is likely that this characteristic is seasonal, as it has been shown that DOC concentrations are at their lowest in winter and spring months in peatland environments (Scott et al., 1998). DOC and discharge also appear to peak concurrently, but the level of discharge increase appears to have less effect on the concentration than with POC. For example, at day three a small peak in discharge $(Q=0.01)$ causes a rapid rise in DOC from $\sim 10-22 \mathrm{mg}^{-l}$, while similar peak concentrations are associated with the largest discharge peak $(Q=0.09)$. As such, 
it appears that the level of discharge increases do not control the increase in DOC concentration (i.e. similar peaks in DOC are forced by very different storm events). This is evidenced by the poor relationship between DOC and discharge. The $Q$-DOC relationship exhibits a low $r^{2}$ value $(0.15)$, caused by the scatter of the DOC concentrations with variable discharges. In comparison, POC correlates much more strongly $\left(r^{2}=0.45\right)$ with these higher discharges in spite of the likely presence of hysteresis loops.

Following DOC peaks, concentrations decline slowly unless discharge remains high and variable. In these conditions, DOC varies less and remains at higher concentrations. Similar observations of falling DOC concentrations following discharge peaks have also been noted by Worrall et al. (2002) who describe DOC flux as a function of a three end-member system, with inter-event water dominated by low DOC while storm flow is dominated by a mixture of DOC rich and poor waters, sourced from old water within the peat profile and rainwater respectively. The author's refer to the rapid rises in DOC as event water (rainfall, runoff and through flow) exports an existing supply of DOC rich water. The authors hypothesise that the time between events and the antecedent conditions will control this supply of dissolved carbon. In contrast to our study, Worrall et al. (2002) sample a period in autumn which is referred to as the re-wetting period of the peatland after the summer. As such, they propose that this flushing of DOC during storm events may be restricted to that time of year as the water table rises through the acrotelm where the DOC is sourced. However, it appears that this study supports the idea of a flushing of an existing carbon supply also during a spring period and that level of increased discharge is not a direct control of the DOC concentration of this flush water.

Due to the rapid increase in DOC concentration, the temporal variability of DOC does appear to vary with discharge on an event scale basis. The slow decline of DOC after such an event and the much smaller overall range of concentrations does mean, however, that the sampling implications of temporal variability in DOC flux are less significant than those identified for POC data. This is highlighted by the results of the flux analysis. As highlighted above, $95 \%$ of POC export occurs in just $8 \%$ or $27 \mathrm{~h}$ of the study period. In comparison, $95 \%$ of DOC export occurs over much longer periods of $\sim 62 \%$ - or over $208 \mathrm{~h}$ ( $>8$ days).

\section{Conclusion}

- In contrast to most previous work on carbon export from peatland catchments, this study has revealed that POC is the dominant component of fluvial organic carbon flux from the Upper North Grain catchment. UNG lies at one end of a spectrum from eroding peatlands through eroded and re-vegetated systems to the intact peatlands where most previous work on the balance of POC and
DOC in runoff has been conducted. The results of this study emphasise the importance of adequately considering the POC flux as a component of the carbon budget in systems where erosion is significant.

- The temporal variability of POC flux demonstrated here means that it is not only important to consider POC flux as a significant part of the carbon budget but that in catchments where it is important, higher resolution sampling than the standard weekly measurement are required to adequately characterise the flux.

- Potential increases in DOC flux associated with climate warming are well documented but the historic association of erosion with periods of climate change combined with the elevated estimates in these data also suggests a risk of increasing POC flux with future environmental change.

- Given the significance of POC flux from eroding systems further research is urgently required to consider the fate of particulate carbon in the fluvial system and the proportion which might be expected to become climatically active.

Acknowledgements. We thank the University of Manchester, School of Environment and Development for the provision of a Graduate Teaching Fellowship (to R. R. Pawson) and Moors for the Future Partnership for the provision of a Small Project Grant for fieldwork and analytical expenses. The authors would also like to thank the National Trust for allowing fieldwork to be carried out at Upper North Grain.

Edited by: S. White

\section{References}

Armstrong, A., Cox, N. J., Warburton, J., Evans, M., and Holliday, V. J.: The effect of rating curve model fit on suspended sediment load estimates and the assessment of model fit, Geophys. Res. Abstr., 8, European Geosciences Union, 2006.

Armstrong, A.: Monitoring and modelling suspended sediment flux in British upland catchments, Unpublished PhD. Thesis, University of Durham, 2005.

Bower, M. M.: The distribution of erosion in blanket peat bogs in the Pennines, Transactions and Papers (Institute of British Geographers), 29, 17-30, 1961.

Bradley, S. B. and Lewin, J.: Transport of Heavy Metals on Suspended Sediments Under High Flow Conditions in a Mineralized Region of Wales, Environ. Pollut., 4, 257-267, 1982.

Bragg, O. M. and Tallis, J. H.: The sensitivity of peat-covered upland landscapes, Catena, 42 345-360, 2001.

Chow, A. T., Guo, F., Gao, S., Breuer, R., and Dahlgren, R. A.: Filter pore size selection for characterizing dissolved organic carbon and trihalomethane precursors from soils, Water Res., 39, 1255-1264, 2005.

Daniels, S.: Controls on Streamwater Acidity in South Pennine Headwater Catchments, Unpublished PhD. Theses, University of Manchester, 2006. 
Dawson, J. J. C., Billet, M. F., Neil, C., and Hill, S.: A Comparison of particulate, dissolved and gaseous carbon in two contrasting upland streams in the UK, J. Hydrol., 257, 226-246, 2002.

Dawson, J. J. C., Billet, M. F., Hope, D., Palmer, S. M., and Deacon, C. M.: Sources and sinks of aquatic carbon in a peatland stream continuum, Biogeochemistry, 70, 71-92, 2004.

Dawson, E. J. and Macklin, M. G.: Speciation of Heavy Metals in Floodplain and Flood Sediments: a Reconnaissance Survey of the Aire Valley, West Yorkshire, Great Britain, Environ. Geochem. Health, 20, 67-76, 1988.

Duan, N.: Smearing estimate - a nonparametric retransformation method, J. Am. Statist. Assoc., 78 605-610, 1983.

Evans, C. D., Jenkins, A., and Wright, R. F.: Surface water acidification in the South Pennines I. Current status and spatial variability, Environ. Pollut., 109, 11-20, 1999.

Evans, M. and Warburton, J.: Sediment budget for an eroding peat moorland catchment in northern England, Earth Surf. Processes and Landforms, 30, 557-577, 2005.

Evans, M., Warburton, J., and Yang, J.: Eroding blanket peat catchments: Global and local implications of upland organic sediment budgets, Geomorphology, 79, 45-57, 2006.

Francis, I. S.: Blanket peat erosion in Mid-Wales: two catchment studies, Unpublished PhD Thesis, University of Wales, Aberystwyth, 1987.

Francis, I. S.: Blanket peat erosion in a mid-Wales catchment during two drought years, Earth Surf. Processes and Landforms, 15, 445-456, 1990.

Freeman, C., Evans, C. D., Monteith, D. T., Reynolds, B., and Fenner, N.: Export of organic carbon from peat soils, Nature, 412, 785, 2001.

Fujii, R., Ranalli, A. J., Aiken, G. R., and Bergamaschi, B. A.: Dissolved Organic Carbon Concentrations and Compositions, and Trihalomethane Formation Potentials in Waters from Agricultural Peat Soils, Sacramento-San Joaquin Delta, California: Implications for Drinking-Water Quality, US Geological Survey Water-Resources Investigations Report, 98-4147, 1998.

Holden, J. and Burt, T. P.: Infiltration, runoff and sediment production in blanket peat catchments: implications of field rainfall simulation experiments, J. Hydrol., 16, 2537-2557, 2002.

Hope, D., Billet, M. F., and Cresser, M. S.: Exports of organic carbon from two river systems in NE Scotland, J. Hydrol., 193, 61$82,1997 \mathrm{a}$.

Hope, D., Billett, M. F., Milne, R., and Brown, T. A. W.: Exports of organic carbon in British rivers, Hydrol. Processes, 11, 325-344, $1997 b$.

Hutchinson, S. M.: Use of magnetic and radiometric measurements to investigate erosion and sedimentation in a British upland catchment, Earth Surf. Processes and Landforms, 20, 293314, 1995.

Kempe, S.: Carbon in the fresh water cycle, in: The global carbon cycle, edited by: Degens, E. T., Kempe, S., and Ketner, P., SCOPE 13, John Wiley and Sons, 317-342, 1979.

Koelmans, A. A. and Prevo, L.: Production of dissolved organic carbon in aquatic sediment suspensions, Water Res., 37, 22172222, 2003.

Labadz, J. C., Burt, T. P., and Potter, A. W. R.: Sediment yield and delivery in the blanket peat moorlands of the Southern Pennines, Earth Surf. Process. Landforms, 16, 255-271, 1991.

Lindsay, R. A., Charman, D. J., Everingham, F., O’Reilly, R. M.,
Palmer, M. A., Rowell, T. A., and Stroud, D. A.: The Flow Country: The peatlands of Caithness and Sutherland. Peterborough, Nature Conservancy Council, 1988.

Littlewood, I. G.: Estimating constituent loads in rivers: a review, Institute of Hydrology, Wallingford, UK, 81, 1992.

Novák, M., Adamová, M., Kelman Wieder, R., and Bottrell, S. H.: Sulfur mobility in peat, Appl. Geochem., 20, 673-681, 2005.

Pawson, R. R., Evans, M. G., and Allott, T. E.: The role of Particulate Organic Carbon (POC) in the carbon cycle of degrading upland peat systems, Geophys. Res. Abstr., 8, European Geosciences Union, 2006.

Rothwell, J. J.: Fluvial export of heavy metals from contaminated and eroding peatlands, southern Pennines, UK, Unpublished PhD Thesis, University of Manchester, 2006.

Rothwell, J. J., Robinson, S. G., Evans, M. G., Yang, J., and Allott, T. E. H.: Heavy metal release by peat erosion in the Peak District, Southern Pennines, UK, Hydrol. Processes, 19, 2973-2989, 2005.

Rothwell, J. J., Evans, M. G., Allott, T. E. H.: Lead contamination of fluvial sediments in an eroding blanket peat catchment, Appl. Geochem., 22, 466-459, 2007.

Scott, M. J.: Temporal Patterns in the chemistry, flux and molecular characteristics of dissolved organic carbon in drainage water from upland peat systems, Unpublished PhD. Theses, University of Manchester, 1998.

Spears, D. A. and Amin, M. A.: A mineralogical and geochemical study of turbidite sandstones and interbedded shales, Mam Tor, Derbyshire, UK, Clay Minerals, 16, 333-345, 1981.

Tallis, J. H.: Blanket mire in the upland landscape, in: Restoration of temperate wetlands, edited by: Wheeler, B. D., Shaw, S. C., Fojt, W. J., and Robertson, R. A., John Wiley, Chichester, 495508, 1995.

Tallis, J. H.: Peat erosion in the Pennines: the badlands of Britain, Biologist, 44, 277-279, 1997a.

Tallis, J. H., Meade, R., and Hulme, P. D. (Eds.): Blanket Mire Degradation: Causes, Consequences and Challenges, Proceedings of the Mires Research Group Meeting at the University of Manchester, 9-11 April 1997b.

Tallis, J. H.: The southern Pennine experience: an overview of blanket mire degradation, in: Blanket Mire Degradation: Causes, Consequences and Challenges, edited by: Tallis, J. H., Meade, R., and Hulme, P. D., Proceedings of the Mires Research Group Meeting at the University of Manchester, 9-11 April 1997c.

Tipping, E., Marker, A. F. H., Butterwick, C., Collett, G. D., Cranwell, P. A., Ingram, J. K. G., Leach, D. V., Lishman, J. P., Pinder, A. C., Rigg, E. and Simon, B. M.: Organic carbon in the Humber rivers, Sci. Tot. Environ., 194/195, 345-355, 1997.

Tipping, E., Smith, E. J., Lawlor, A. J., Hughes, S., and Stevens, P. A.: Predicting the release of metals from ombrotrophic peat due to drought-induced acidification, Environ. Pollut., 123, 239-253, 2003.

Wallage, Z., Holden, J., and McDonald, A. T.: Drain blocking: An effective treatment for reducing dissolved organic carbon loss and water discolouration in a drained peatland, Sci. Tot. Environ., 367, 811-821, 2006.

Walling, D. E. and Webb, B. W.: Estimating the discharge of contaminants to coastal waters by rivers: Some cautionary comments, Mar. Pollut. B., 16 488-492, 1985.

Wolverson-Cope, F.: Geology Explained in the Peak District, David 
and Charles, Devon, 1976.

Worrall, F., Burt, T. P., Jaeban, R. Y., Warburton, J., and Shedden, R.: Release of dissolved organic carbon from upland peat, Hydrol. Processes, 16, 3487-3504, 2002.

Worrall, F., Reed, M., Warburton, J., and Burt, T. P.: Carbon budget for a British upland peat catchment, The Sci. Tot. Environ., 312, 133-146, 2003a.
Worrall, F., Burt, T., and Sheddon, R.: Long Term records of riverine carbon flux, Biogeochemistry, 64, 165-178, $2003 \mathrm{~b}$.

Worrall, F. and Burt, T.: Predicting the future DOC flux from upland peat catchments, J. Hydrol., 300, 126-139, 2005. 